\title{
The effectiveness of studying foreign language in the intercultural communication
}

\author{
Anna Kononenko ${ }^{1 *}$, and Larisa Nedospasova ${ }^{2}$ \\ ${ }^{1}$ Rostov State Transport University, 2, Rostovskogo Strelkovogo Polka Narodnogo Opolcheniya sq., \\ Rostov-on-Don, 344038, Russia \\ ${ }^{2}$ Rostov State Transport University, 2, Rostovskogo Strelkovogo Polka Narodnogo Opolcheniya sq., \\ Rostov-on-Don, 344038, Russia
}

\begin{abstract}
The variety of the intercultural communication provides the existence of different methods and tools that appear in learning process using the intercultural interaction in preparing future specialists. For understanding the intercultural communication it should be combined the knowledge and understanding another culture language. Moreover, the developing intercultural communication process should be seen in practice if the students have opportunities to develop language skills of the intercultural communication in daily routine or in professional situations conducted at the different learning classes with using modern pedagogical methods. One of the most effective ways of intercultural communication is a motivation to learn a foreign language for special occasions aimed at obtaining professional skills and professional experience. Achieving a high professional level of language training is directly related to the peculiarities of a foreign language culture. The proposed method is based on communicative competence of learners with practical implementation in the professional sphere. The method under consideration makes it possible to give conclusions about necessity for studying a foreign language and pay attention to filling the learning language content using professional direction. Nowadays, the professionals with high level of the foreign language in various fields are highly competitive and indispensable now. The obtained results of the research based on the effectiveness of modern methods' use and application in the classroom for preparing future specialists.
\end{abstract}

\section{Introduction}

In the context of the international standards' implementation for student professional activity of non-linguistic universities, the improvement of the communicative competencies in a foreign language is provided to ensure the high-quality performance of the professional aims for intercultural interaction and understanding in situations of the foreign language communication in oral or written forms.

\footnotetext{
* Corresponding author: kononenkocap1@email.ru
} 
The purpose of the research is to form students' professional communicative competencies with effectiveness in the process of the foreign language professional communication in standard-known and unknown-standard situations of the interpersonal, business and professional aspects with foreign citizens in the performance of professional duties and responsibilities. For achieving the result, the learning process is aimed at improving the professional competence in the field of the professional documentation, colloquial clichés and vocabulary in a foreign language, which have become widespread in all life's spheres, given widely in the worldview of foreign languages in cultural and professional connections, in the field of the professional development, research and teaching. The impacts and challenges of these transformations require careful learning. The students of the institute or university prospect for future work, express motivation in mastering a foreign language as part of their career priorities in a professional environment. The main tendencies due to intercultural communication are aimed among students as they must perceive the real globalization of the world and understand a foreign language environment.

The development of a foreign language as an international tool communication is reaching the level of using such language as a popular one. It has been repeatedly emphasized and substantiated by scientists and linguists $[1,5]$ and others. The modern world is characterized by the fact that a foreign language becomes the main criterion in determining the employment possibility both in Russia and abroad. The general and specific problems of preparing future specialists for intercultural communication as specific purposes with a native speaker of a foreign language were studied by [6-15]. Modern higher education is developing and this concerns the renewal of the needs, content and methods of teaching a foreign language focused on communicative competence [16]. All methods are also taken and used in teaching practice.

\section{Materials and methods}

The research methodology is based on the method of comparison and generalization, which makes it possible to draw more accurate conclusions. For modern linguists, it is obvious that future specialists get professional knowledge of the foreign languages from different processes in the sphere of the international relations and socio-economic structure, the expansion of cooperation within the limits of economic and political globalization [13]. The influence of the language cultural and professional communication in teaching foreign languages, particularly, concerning students of various universities, has not been sufficiently studied. The effectiveness of the studying foreign language in the intercultural communication considered in this research paper is a descriptive method in a new aspect of the special inevitable process in teaching a foreign language to students at the Russian universities and institutes as a reflection of the necessity in learning intercultural interaction. The teaching process analysis of training foreign language is aimed at studying intercultural communication in the modern world and students are a reflection of modern culture and professional communication. As a result, the successful spread and popularity of the foreign languages around the world in any field of human functioning and relevance as a tool for multivariate communication activities have vitally seen. It is apparent that the learning one foreign language has become the rule of intercultural interaction, as it gives opportunity to study and learn about the cultures of different countries. The educational potential of a technical university is revealed with the help of the methodological tools of social and psycho-pedagogical disciplines [14]. 
Table 1. Iintercultural communication as a characteristic of the sociocultural competence.

\begin{tabular}{|c|c|c|c|}
\hline \multicolumn{4}{|c|}{ Intercultural communication is the main activity of the modern people } \\
\hline \multicolumn{2}{|c|}{ Language level } & Communication etiquette \\
\hline $\begin{array}{c}\text { Language } \\
\text { proficiency }\end{array}$ & $\begin{array}{c}\text { Communications } \\
\text { behavior }\end{array}$ & $\begin{array}{c}\text { Sociocultural } \\
\text { knowledge }\end{array}$ & $\begin{array}{c}\text { Multicultural } \\
\text { education }\end{array}$ \\
\hline
\end{tabular}

Nevertheless, the foreign language is recognized as a valuable component of modern life. Trends in world progress have a significant impact on the academic content of teaching a foreign language in higher educational institutions of a non-linguistic profile, namely: jurisprudence, medicine, science, engineering industries, information technology and others [15]. Currently, it is observed how the modern language education content in the universities is oriented for gaining a successful level that meets the world life requirements. The learning priority of a foreign language is determined by reality, which provides everyday evidence that the foreign language is becoming an increasingly important influential powerful tool for the international exchange of information in professional and scientific communication. In higher education, the students are focused on specific goals that are closely related to a sufficient knowledge of a foreign language, it is considered necessary for their career. This can motivate non-linguistic students to master a foreign language in order to realize their abilities in professional environment [16]. Moreover, the intercultural communication serves as an additional motivating factor that plays a vital role in linguistic achievement which leads to continuing education, gaining advantages for challenge and career advancement. The employers approve such educational institutions which provide them with foreign language proficient employees according to their special work environmental areas. The foreign language teachers at non-linguistic universities believe that the students preparing oriented on professional sphere is not limited to learning the special vocabulary, but it is aimed at studying intercultural interaction with special profile disciplines that are used in professional activities. The educational potential of a technical university is revealed with the help of the methodological tools of social and psycho-pedagogical disciplines.

Table 2. Different fields of the intercultural communication.

\begin{tabular}{|c|c|c|}
\hline \multicolumn{3}{|c|}{ Formation of the students' professional orientation } \\
\hline Studying disciplines & & xpected learning outcomes \\
\hline $\begin{array}{c}\cdot \text { Economy } \\
\cdot \text { Jurisprudence } \\
\cdot \text { Journalism } \\
\text { •Information Technology } \\
\text { - Advertising and public relations } \\
\cdot \text { Engineering disciplines } \\
\cdot \text { Medicine } \\
\cdot \text { Science }\end{array}$ & $\begin{array}{l}\text { 1) } \\
\text { 2) }\end{array}$ & $\begin{array}{l}\text { the originality of a foreign language } \\
\text { culture and values of a foreign } \\
\text { language community; } \\
\text { the language system of knowledge } \\
\text { and inherent understanding in the } \\
\text { culture of studying foreign } \\
\text { language; } \\
\text { the conventional basics of verbal } \\
\text { communication in a foreign } \\
\text { language community, the rules and } \\
\text { traditions of intercultural and } \\
\text { professional interaction; } \\
\text { the nessecary skills to organize and } \\
\text { manage intercultural } \\
\text { communication; } \\
\text { the ability to conduct professional, } \\
\text { including research and activities in } \\
\text { the international environment. }\end{array}$ \\
\hline
\end{tabular}


The university teachers shall educate students for effective intercultural communication in their professional situations, which are the teaching practical method of a foreign language, and this requires knowledge of the foreign language culture and history. The intercultural communication consists of the linguistic, psychological and sociocultural foundations of intercultural communication and it is the interaction between people in socio-cultural activities for the exchanging information through natural or artificial language. The information can be varied and relates to different spheres of human activity: work, study, travel, marriage and so on. The necessary condition for the implementation of the intercultural communication is the presence of the common language communication. When studying a foreign language, the following aspects are used particularly:

Table 3 Intercultural communicative competence.

\begin{tabular}{|c|c|}
\hline \multicolumn{2}{|c|}{ Effectiveness of intercultural communication } \\
\hline Human activities & Foreign language culture \\
\hline $\begin{array}{c}\text { Travelling } \\
\text { Study } \\
\text { Marriage } \\
\text { Job } \\
\text { Career } \\
\text { Moving abroad } \\
\text { Business }\end{array}$ & $\begin{array}{l}\text { - Historical and social knowledge of the } \\
\text { language country; } \\
\text { • Cultural traditions; } \\
\text {-Psychological features in behavior; } \\
\text { • Etiquette; } \\
\text { - Rules of business etiquette (work); } \\
\text { • Health and nutrition; } \\
\text { - General knowledge of the country`s } \\
\text { political and economic situation. }\end{array}$ \\
\hline
\end{tabular}

It is underlined that language communication with students plays a huge role for the tutor as it is stimulating the interlocutor to react, to act in real professional situations, purposes contributing to the decision of the cognitive tasks related to professional subjects with learning foreign languages [17]. The rapid development of the information technology affects the pedagogical model of educational process, teacher knowledge and teacher training. The teacher should be qualified and have special subject knowledge to create or plan a language improvement course tailored to the average level of the academic group and individuals. The knowledge level is one of the basic principles of the communicative approach. This motivates students to learn a foreign language, and sometimes they master several languages. One-to-one learning refers to a "learner-centered approach" and it rewards students in learning and practicing their best abilities for the expected learning outcomes [18]. The clear requirements for the fulfillment of the assigned aim of the teacher before the tasks have been proposed in communication situations, helps to continue studying the professional foreign language [19]. It should be noted the specificity of the cultural content of the educational program in the discipline of a foreign language. In addition, the lexical priority is the main educational condition, as students start to learn a foreign language with words, phrases and speech and grammar structures. The geographic and economic state of the country influences the choice and preference learning of a foreign language among students.

\section{Results}

The academic and professional relations between higher education institutions, participation in the international community, joint international scientific, academic and professional activities reflect the urgent relevancy for professionals who speak a foreign language as a way of the international professional communication [20]. The intercultural communication consists of the ability to compare different foreign language cultures, to use 
various approaches for establishing contact with representatives of other cultures, to interact with such representatives, eliminating misunderstandings and conflict situations caused by using intercultural differences. The interpretation of linguistic material is in the development of the national written literary language [21].

A tutor of a foreign language, who understands the didactic intentions, imposes mandatory primary rules of conduct in accordance with the hospitality of the country of the target language, which students obey in the classroom in the academic group. The most popular tutor strategies are to use role-playing games, to conduct the round tables, to initiate debates, to do project activities, to implement the case analysis, to work with professional documents, to simulate the scientific conferences on industry issues and to pay attention to the national cultural characteristics. The educational language content consists of forms such as case study, role-playing games, culture-oriented discussions and presentations that contribute to more effective training for intercultural communication. Accordingly, the student's intercultural communication, which is an inherent preparation of a professional in modern requirements is possessing a better language understanding.

The different models of the professional activity that imitate the process and conditions of future work environment are meaningful in the language educational process as a logistician observes the documentation at the port, a manager sends a business letter asking for the value of the goods, a lawyer helps a foreign citizen fill out a statement of a theft, an engineer agrees on internship abroad by phone with a representative of a foreign university. As a result, the students can be divided into groups according to selected countries, for example: countries of Europe and Asia; give them a task, for example: to develop a research group project, to solve a professional problem, to obtain necessary information, to fill out routine documents according to the provided information, to make an entry and prepare a report. To cope with given task, students interact with each other using intercultural communication and within the criterion of modern teaching methods; the key approaches involve the concept of the professionally oriented communicative competence. The results obtained and their originality is based on practical teaching of a foreign language.

Table 4. Student's learning language content.

\begin{tabular}{|c|c|}
\hline \multicolumn{2}{|c|}{ Student`s learning language content } \\
\hline $\begin{array}{c}\text { Professional activity } \\
\text { Intercultural activity }\end{array}$ \\
\hline $\begin{array}{c}\text { Challenges } \\
\text { motivation }\end{array}$ \\
\hline $\begin{array}{c}\text { Co develop the new subjects` knowledge in order to teach effectively; } \\
\text { to understand the learning content and the language; } \\
\text { to increase the language proficiency; }\end{array}$ \\
to raise the level of the universal and professional competences; \\
to motivate students to study different foreign languages and cultures; \\
to increase interest in training programs abroad; \\
to establish friendly contacts with the native speakers.
\end{tabular}

A comprehensive study of the intercultural speech clichés is carried out, the professional colloquial vocabulary is investigated, the modern trends and factors affecting the actualization of teaching professional intercultural communication in a foreign language are investigated. For choosing teaching methods, tools and techniques, it is important to focus on the cognitive-search, problematic, debatable and research, as all aspects of the language proficiency should be developed. Some aspects as the understanding, memorization and mastering the foreign language are to provide graduates with the ability to have the required language level including the language proficiency in the intercultural 
communication. The necessity of the educational and international perspectives underlines the special requirements for qualified specialists with professional knowledge of the foreign languages. Furthermore, the use of the acquired knowledge of a foreign language will find its application in design, production and technology, organizational and management, research activities and cross-industry specialization.

Consequently, both the foreign language and intercultural communication as a union performs the considerable role in preparing students of the university. It is practically used the results that could be considered as the implementation of graduates' effective preparation including the integrity of the "professional language" based on the supplementary materials, books and other literature for teaching a foreign language combined with cultural, linguistic and intercultural training. The understanding the studied language culture and usage of the professional subject have a certain set of the intercultural knowledge: lexical and grammatical structures, use of language, phraseological units, realities of the language; the rules of communication and etiquette and social sphere as the history of the country, its holidays, traditions and national characteristics. The foreign language like academic discipline is closely connected with intercultural communication which combines the effectiveness of studying foreign language and choosing the suitable teaching method. In addition, knowledge of the language is a communicatively sufficient level in the modern world and it establishes the business, scientific, educational and economical contacts between specialists in different social spheres.

\section{Discussion}

The obtained results are intended to improve the communicative competencies of the students in the implementation of their professional activities related to communication with foreign citizens visiting our country or working in conjunction with the Russian companies, institutions and others. Future specialists are to participate in discussions, consulting, conferences, and conversations with foreign experts in their processional field. It is assumed that a graduate of the institute or university must have a good spoken language and can communicate and establish relations with foreign representatives. For achieving better results, students take part at seminars, listen to the lectures of the outstanding professors; participate at the international language or professional conferences and publish their graduate thesis in the international scientific proceedings. The intercultural communicative aspect is one of the tools to motivate non-linguistic students to master a foreign language. The obtained results confirmed that a significant number of students agree with requirements to implement the foreign language proficiency in practical professional activities, based on the capability to be engaged in the cooperative international projects, work abroad, communication and collaboration with colleagues from other countries and so on.

\section{References}

1. D. Matsumoto, H. C. Hwang, Cross-Cultural Research, 40(5), 439-460 (2015), doi: $10.1177 / 1069397115599542$

2. J. W. Neuliep, Journal of Intercultural Communication Research, 41, 1-16 (2012), doi: 10.1080/17475759.2011.623239

3. A. Tashchian, W. R. Forrester, M. Kalama, Journal of International Education Research, 10 (1)1, 29-36 (2014), doi: 10.19030/jier.v10i1.8348

4. A.-K. Ward, E. C. Ravlin, B. S. Klaas, R. E. Ployhart, N. R. Buchan, Journal of Applied Psychology, 101(10), 1498-1511 (2016), doi: 10.1037/apl0000144 
5. K. Taylor-Leech, A. J. Liddicoat, Current Issues in Language Planning, 15, 353-360 (2014), doi:10.1080/14664208.2014.927956

6. S.M. Croucher, M. Sommier, D. Rahmani, Communication Research and Practice, 1:1, 71-87 (2015), doi: 10.1080/22041451.2015.1042422

7. T. V. Belysheva, In Proceedings of the III Intern. Scientific Conf., 52-55(2017), URL: https://moluch.ru/conf/ped/archive/269/12828/

8. I. Hanssen, L.-M. Alpers, Journal of Intercultural Communication, 23 (2010)

9. M.-S. Kim, Asian Journal of Communication, 20, 166-180 (2010), doi:10.1080/01292981003693351

10. G. Awada, Journal of Intercultural Communication Research, 50(2), 166-184 (2021), doi: 10.1080/17475759.2020.1839941

11. W. S. Ward, A. F. Southwell, Journal of Intercultural Communication Research, 50(2), 122-145(2021), doi: 10.1080/17475759.2020.1782970

12. G. L. Deniz, K. A. Noels, System, 97 (2021), doi.org/10.1016/j.system.2020.102443

13. Z. M. Huang, Language and Intercultural Communication, 21(1), 83-101(2021), doi: 10.1080/14708477.2020.1833898

14. V. Kolmakova, D. Shalkov, and O. Baryshnikova, 18023 (2020), https://doi.org/10.1051/e3sconf/202021018023

15. S. López-Rocha, Language and Intercultural Communication, 21(1), 118-131 (2021), doi: 10.1080/14708477.2020.1833900

16. O. N. Bessarabova, E. S. Shefieva, M. P. Churikov, Engineering education and training systems for graduates of technical universities for carrying out professional activities in the leading countries of the world, 244 (2016)

17. S. López-Rocha, Language and Intercultural Communication, 21(1), 118-131 (2021), doi: 10.1080/14708477.2020.1833900

18. T. Seregina, S. Zubanova, V. Druzhinin, G. Shagivaleeva, Space and Culture, 7(3), 243-253 (2019), doi.org/10.20896/saci.v7i3.524

19. A. P. Kononenko, L.A. Nedoseka, Modern Pedagogical Education, 6, 164-167 (2020)

20. T. E. Isaeva, Society: Sociology, Psychology, Pedagogy, 2, 59-61 (2017)

21. D. Y. Shalkov, V. V. Kolmakova, E. S. Shilova, 198, 136-144 (2021), https://doi.org/10.1007/978-3-030-69415-9_16 